\author{
Н.О. Королюк ${ }^{1}$, Д.Ю. Голубничий ${ }^{1}$, Я.Г. Поліщук ${ }^{2}$ \\ ${ }^{1}$ Харківський національний університет Повітряних Сил ім. I. Кожедуба, Харків \\ ${ }^{2}$ Військова частина А0306, Вінниия
}

\title{
ОБГРУНТУВАННЯ ПІДХОДУ ЩОДО ОЦІНКИ ПРОПУСКНОЇ СПРОМОЖНОСТІ В ІНФОРМАЦІЙНО-ТЕЛЕКОМУНІКАЦІЙНІЙ МЕРЕЖІ ПОВІТРЯНИХ СИЛ
}

У статті в результаті проведеного аналізу встановлено, щзо основою інформаційної інфраструктури є сучасні мультисервісні телекомунікаційні мережі, ефективність функиіонування яких з урахуванням досвіду операції об'єднаних сил залежить від ступеня автоматизації та інтелектуалізації. Визначені вимоги до системи зв'язку, які необхідні для забезпечення якісного управління частинами та підрозділами Повітряних Сил. Обрунтована доичільність використання єдиного підходу щзодо оиінки пропускної спроможності в інформаційно-телекомунікаційних мережах Повітряних Сил. Визначенні шляхи щуодо досягнення необхідного рівня пропускної спроможності системи зв'язку, щьо дозволяють в складних умовах обстановки забезпечити якість пропускної спроможності не нижчі вимагаємої. Запропонований метод балансування навантаження мережі, який забезпечує статистично рівномірний розподіл навантаження на серверах, високі показники продуктивності, пропускної спроможності, відмовостійкості.

Ключові слова: оцінка пропускної спроможності мережі, інформаційно-телекомунікаційна мережа Повітряних Сил, метод балансування навантаження.

\section{Вступ}

Постановка проблеми. Досвід збройних конфліктів останніх десятиліть, в тому числі на території Донецької та Луганської областей України, свідчить про зростання складності та динамічності обстановки в ході підготовки та ведення бойових дій. Це обумовлює підвищення значення боротьби у повітряному просторі для досягнення успіху не лише в окремих операціях збройних сил, але й у війні в цілому [1-2]. Досягти цього можливо тільки шляхом створення ефективної системи управління, що функціонує в єдиному інфокомунікаційному просторі, здатної в реальному масштабі часу обробляти інформацію, виробляти управляючі дії (доводити оперативну інформацію, накази і команди до бойових платформ). Основою інформаційної інфраструктури $є$ сучасні мультисервісні телекомунікаційні мережі, ефективність функціонування яких 3 урахуванням досвіду ООС та АТО залежить від ступеня автоматизації та інтелектуалізації, що забезпечує максимально можливу ефективність системи телекомунікації за рахунок раціонального (оптимального) використання мережних ресурсів.

Створення сучасної інформаційнотелекомунікаційної мережі (ITKM) Повітряних Сил (ПС) Збройних Сил здійснюється в рамках концепції NGN (Next Generation Network), що дозволяє переносити різнорідну за складом інформацію 3 наданням широкого спектру послуг із заданими значеннями обраних показників якості обслуговування.
Пропускна спроможність ITM ПС, побудованих за принципами NGN, багато в чому залежить від ефективності реалізації функцій системи управління мережними ресурсами, до числа яких, відносяться засоби управління, оцінки трафіка.

На сьогоднішній час спостерігається стрімке зростання обсягу трафіку даних і значне зростання потреб у розмірах інформаційних потоків в процесі надання видів послуг. Це призводить до того, що існуючі телекомунікаційні мережі виявилися неспроможними або підійшли до межі своїх можливостей по обслуговуванню абонентів 3 заданими показниками якості обслуговування, вирішення задач управління трафіком практично не узгоджені. Існуючі засоби оцінки, управління трафіком, що відповідають за його формування, розподіл (маршрутизацію) i обмеження інтенсивності, носять розподільчий характер. Евристичні моделі оцінки, управління трафіком (пошуку найкоротшого шляху в мережі, корзини маркерів і дірявого відра) не здатні врахувати зміну поточного навантаження мережного вузла, характеристики трафіків користувачів.

В зв'язку з цим виникає актуальна задача по розробці підходу щодо оцінки пропускної спроможності ІТКМ ПС та формування рекомендацій щодо балансування навантаження під час передачі інформації.

Аналіз останніх досліджень і публікацій. В роботі [3] запропоновані основні концептуальні підходи щодо побудови системи управління мережами 
зв'язку військового призначення. Визначені поняття предметної області, цілі функціонування системи управління, обгрунтовані принципи іiі побудови, структура та функції, показники та критерії ефективності. В монографії [4] розкриті системні проблеми та способи їх вирішення при організації управління сучасними телекомунікаційними мережами. Розглянуті основні положення по організації автоматизованого управління зв'язком, приводиться iii архітектура та основні задачі мережевого управління. Представлені моделі мереж зв’язку, приведені поняття, які визначають ефективність управління мережами та способи їх оцінки, методи та алгоритми рішення задач управління комутаційним обладнанням та телекомунікаційними мережами. В роботі [5] розглядаються найбільш відомі системи моніторингу, оцінки пропускної спроможності телекомунікаційних мереж, представляється їх порівняльний аналіз, формулюються загальні вимоги та синтезується загальна архітектура подібних систем. Запропоновані рішення не здатні прогнозувати стан, оцінювати пропускну спроможність ІТКМ ПС, тому в такі системи необхідно включати додаткові модулі обробки статистичної інформації.

Таким чином проведений аналіз основних публікацій показав, що єдиного підходу щодо оцінки пропускної спроможності в ІТКМ ПС не існуе.

Мета статті. Обгрунтування єдиного підходу щодо оцінки пропускної спроможності в ІТКМ ПС та формування рекомендацій щодо балансування навантаження мережі під час передачі інформації.

\section{Виклад основного матеріалу}

Аналіз показав, що існує багато програм, які здійснюють моніторинг та контроль мережевого трафіку: BMExtreme, BWMeter, Bandwidth Monitor Pro, Wireshark, CommTraffic та багато інших. Важливою задачею при моніторингу трафіку $є$ визначення пропускної спроможності мережі, яка показує максимальний об'єм інформації переданий за одиницю часу. Фактично, пропускна спроможність показує швидкість виконання внутрішніх мережевих операцій (передача пакетів 3 даними через всі комунікаційні вузли). Критерії, що оцінюють пропускну здатність мережі, добре відображають якість виконання мережею основних функцій та відрізняються обраною одиницею виміру кількості переданої інформації, характером даних, кількістю точок вимірювання переданого трафіку, способом усереднення результатів. Пропускну спроможність можна вимірювати між двома вузлами, точками мережі, наприклад, між клієнтським комп'ютером і сервером, між вхідними та вихідними портами маршрутизатора. Для аналізу і налаштування мережі корисно знати дані про пропускну спроможність окремих елементів мережі. В мережах, де дані до вузла призначення зазвичай проходять через кілька транзитних проміжних етапів обробки, доцільно в якості критерію ефективності розглядати пропускну спроможність окремого проміжного елемента мережі.

Знання загальної пропускної спроможності між двома вузлами не може дати повної інформації про можливі шляхи iii підвищення, так із загальної цифри не можна зрозуміти який з проміжних етапів обробки пакетів в найбільшою мірою гальмує роботу мережі. Дані про пропускну спроможність окремих елементів мережі можуть бути корисні для прийняття рішення про способи ііі оптимізації. Тоді має сенс визначити загальну пропускну спроможність мережі як середню кількість інформації, переданої між усіма вузлами мережі в одиницю часу. Для підвищення пропускної спроможності складеного шляху необхідно звернути увагу на самі повільні елементи - в більшості випадків таким елементом, швидше за все, буде маршрутизатор. Слід підкреслити, якщо переданий по складеному шляху трафік буде мати середню інтенсивність, яка перевищує середню пропускну спроможність самого повільного елемента шляху, то черга пакетів до цього елемента буде рости теоретично до нескінченності, а практично - до тих пір, поки не заповниться його буферна пам'ять, а потім пакети просто почнуть відкидатися і втрачатися.

До основних факторів, що приводять до підвищення ролі оцінки пропускної спроможності та формування рекомендацій щодо балансування навантаження в ІТКМ ПС, відносяться:

- ускладнення мереж зв'язку та технологічна несумісність окремих підмереж ІТКМ, обумовлена їхньою неоднорідністю за рахунок мультиінтеграції та гібридизації сучасних телекомунікаційних технологій: ATM (Asynchronous Transfer Mode), IP (Internet Protocol), FrameRelay, X.25, SDH (Synchronous Digital Hierarchy), PDH (Plesiochronous Digital Hierarchy);

- необхідність підтримки неоднорідного, як правило, апаратно та протокольно несумісного телекомунікаційного середовища на базі обладнання зв'язку різних фірм-виробників Multivendorenvironment (Lucent, Avaya, Nortel, Ericsson, Siemens, Alcatel, Tellabs, Memotec, ECI, $\mathrm{RAD}$, Cisco, Newbridge тощо), що безпосередньо диктується новими економічними умовами, в основі яких - конкуренція та відкритість;

- мультисервісна підтримка та підвищення вимог користувачів до кількості, змісту, а головне якості пропонованих послуг;

- можливість деградації структури системи через низьку експлуатаційну надійність мережних елементів або наявності антагоністичного зовнішнього впливу; 
- непередбачувана, як правило стрибкоподібна, зміна абонентського навантаження на вузли транспортної мережі ІТКМ від мереж доступу;

- “несанкціонована" зміна параметрів продуктивності мережних вузлів і пропускної здатності трактів передачі, обумовлена збоями мережного програмного та апаратного забезпечення.

Урахування вищенаведених факторів призводить до необхідності перегляду принципів і підходів щодо оцінки пропускної спроможності ІТКМ ПС.

Існують декілька альтернатив виявлення/уникнення перевантаження: контроль наповненості та середнього часу зайнятості вхідних буферів, найбільш прийнятний при розділених вхідних чергах; контроль використання вихідних ліній; аналіз кругових затримок пакетів; постійне відстежування стану мережі, використовуючи певну схему дослідження.

В даному випадку пропускна спроможність ІТКМ ПС дозволяє оцінити можливість мережі справлятися з піковими навантаженнями, характерними для особливих періодів роботи мережі.

В даний час активно впроваджуються технології IP-мереж, що використовують пакетну передачу даних, яка забезпечує ефективне завантаження каналів зв'язку, однак при управлінні вимагають використання складних протоколів, на обробку яких потрібно процесорний час комутаційного обладнання. Комутаційне обладнання характеризується двома показниками пропускної спроможності: швидкість інтерфейсів в бітах на секунду і продуктивність обладнання - в пакетах в секунду (“Mpps”).

Результати аналізу продуктивності комутаційного обладнання спрямовані на користувача, не враховують можливість роботи обладнання протягом довгого часу. Наприклад, виробники мережевого обладнання Cisco, Juniper та НР в характеристиках приводять продуктивність в Mpps, але вимірювання продуктивності виконано тільки для одного розміру пакета (найчастіше 64 байт) і без використання мережевого функціоналу (Static routing, ACL, NAT).

Для первинної оцінки максимальної продуктивності використовується формула (1), але вона не враховує логіки обробки пакетів.

$$
S=\frac{B}{8 \cdot b}
$$

де $S$ - продуктивність, Мп/с;

$B$ - трафік, Мбіт/с;

$b$ - середня довжина пакетів, байт.

При обробці кожного IP-пакета необхідно вирішити наступні завдання:
- розбір IP-заголовка 3 визначенням IP-адреси одержувача і відправника, протоколів IV рівня і номерів портів;

- перевірка в списках доступу адреси відправника і одержувача, протоколів і номерів портів;

- перевірка адрес в NAT-таблиці для прийняття рішення про трансляцію адрес і портів;

- перевірка адреси призначення по таблиці маршрутизації для прийняття рішення про шляхи доставки; перетворення адрес III рівня в адреси II рівня в мережах загального доступу;

- заміна IP-адрес, внесення в NAT-таблицю, запуск таймерів на кожен запис; перепакування IPпакетів, формування кадрів канальних технологій;

- аналіз отриманих та встановлення своїх міток QoS, постановка в пріоритет черг.

Ці специфічні завдання для обробки кадрів не враховують загальносистемних завдань: ведення журналу кількості прийнятих і переданих даних на кожному інтерфейсі, управління трафіком, розв'язка колізій. При цьому, як правило, заявлена виробником пропускна спроможність значно перевищує справжню.

Тому виникає необхідність розрахунку мережі (завантаження ліній, комутаційних вузлів) для подальшого застосування результатів в обчисленнях продуктивності обладнання, де аргументами є: середній розмір пакетів; метод аналізу заголовка пакетів (протокол); розміри адресної таблиці, списків доступу, таблиці трансляції адрес.

Для дослідження продуктивності обладнання, пропускної спроможності запропонована модель (рис. 1). Генератор пакетів формує трафік, який надходить на один з портів комутаційного пристрою, 3 іншого порту трафік фіксується аналізатором.

Після чого вхідний (трафік А) і вихідний (трафік Б) трафіки порівнюються. Для детального аналізу продуктивності ставиться експеримент з різною довжиною пакетів та виконується на різному устаткуванні, виявляється залежність продуктивності, яка буде основою для розрахунку. Розрахунок необхідної пропускної спроможності в пакетних мережах досить складний і навряд чи дозволить отримати точні результати. Це пов'язано 3 величезною кількістю чинників (особливо властивих сучасним мультисервісних мереж), які досить складно передбачити. У IP-мережах загальна інфраструктура, як правило, використовується безліччю додатків, кожне 3 яких може використовувати власну, відмінну від інших модель трафіку.

Причому в рамках одного сеансу трафік, що передається в прямому напрямку, може відрізнятися від трафіку, що проходить в зворотному напрямку. 


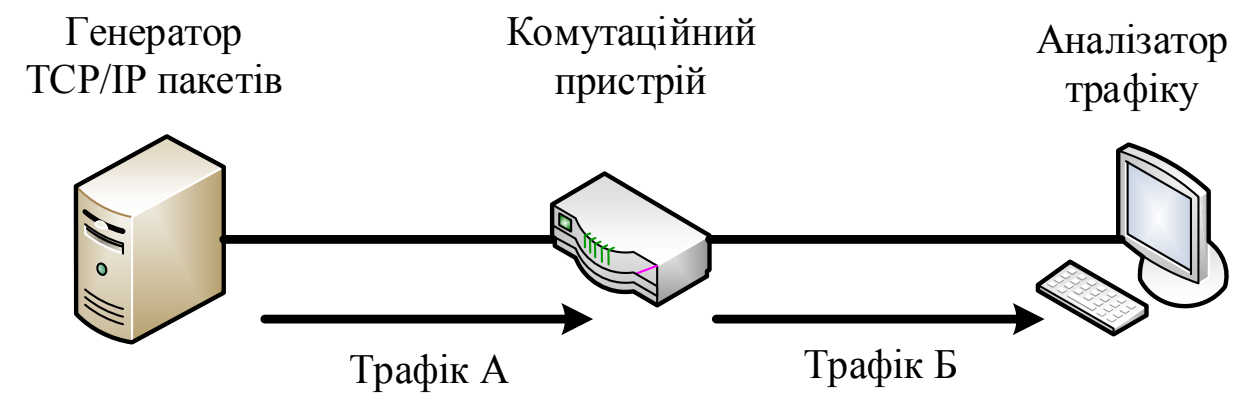

Рис. 1. Модель мережі для дослідження продуктивності мережевого обладнання

Для досягнення високих показників продуктивності, пропускної спроможності, зменшити час відгуку в розподіленим системах доцільно балансування навантаженням мережі 3 метою управління трафіком для розподілу навантаження i/aбо максимального використання всіх серверів в кластері. Механізм збору інформації про завантаженість системи визначає джерело інформації, час збору даних про завантаженість, місце зберігання інформації.

Існує кілька класів механізмів збору інформації.

По-перше, збір даних за потребою. В даному класі використовуються розподілені алгоритми, які збирають інформацію про завантаженість, коли вузол потребує балансуванню навантаження.

По-друге, періодичний збір даних. Алгоритми даного класу можуть бути як централізованими, так і розподіленими. Залежно від зібраних даних, алгоритм ініціює балансування навантаження.

По-третє, збір даних щодо зміни стану. У системах, що реалізують алгоритми даного класу, вузли самі поширюють інформацію про зміну завантаженості при зміні внутрішнього стану.

Ефективність алгоритмів балансування навантаження визначається декількома показниками:

- пропускна спроможність використовується для оцінки загальної кількості завдань, які успішно завершені.

Висока пропускна спроможність необхідна для загальної продуктивності системи;

- час міграції визначається як загальний час переходу завдання від одного вузла або ресурсу до іншого. Воно повинно бути зведене до мінімуму;

- час відгуку вимірюється як інтервал часу між відправленням запиту й одержанням відповіді. Воно повинно бути зведене до мінімуму, щоб підвищити загальну продуктивність;

- відмовостійкість вимірюе здатність алгоритму рівномірно виконувати балансування навантаження в разі будь-якого збою.

Хороший алгоритм балансування навантаження повинен, бути нечутливим до несправностей;

- витрати пов'язані з роботою будь-якого алгоритму балансування навантаження і вказують на вартість процесів, що беруть участь у вирішенні задачі, перерозподілі процесів. Вони повинні бути якомога менше;

- використання ресурсів використовується для забезпечення належного використання всіх ресурсів, які включені в систему. Даний показник повинен бути оптимізований для ефективності алгоритму балансування навантаження;

- масштабованість - здатність алгоритму виконувати рівномірну балансування навантаження в системі відповідно до вимог при збільшенні числа вузлів. Кращим $\epsilon$ алгоритм 3 високою масштабованість;

- продуктивність може бути визначена як ефективність системи.

Даний показник повинен, бути поліпшений при розумних витратах, наприклад, зменшуючи час відгуку зберігаючи допустимі затримки.

Система балансування навантаження складається 3 групи серверів і балансувальника навантаження (рис. 2).

У кожен момент на балансувальник надходить трафік інтенсивністю, що відноситься до класу обслуговування, який необхідно доставити на сервер для обробки, не перевищуючи заданих максимально допустимих значень затримки максимально допустимого відсотка втрат в залежності від їх поточного завантаження і реальної пропускної спроможності в конкретний момент часу:

Балансувальник навантаження і сервера з'єднані між собою двосторонніми мережевими зв'язками 3 максимальною пропускною здатністю, які мають доступну пропускну спроможність момент часу. Моніторинг стану серверів і вільної пропускної спроможності можна здійснити трьома способами:

- після кожного запиту, що поступив;

- в фіксовані проміжки часу, які визначаються статичним алгоритмом;

- в нефіксовані проміжки часу, які визначаються динамічним алгоритмом. 


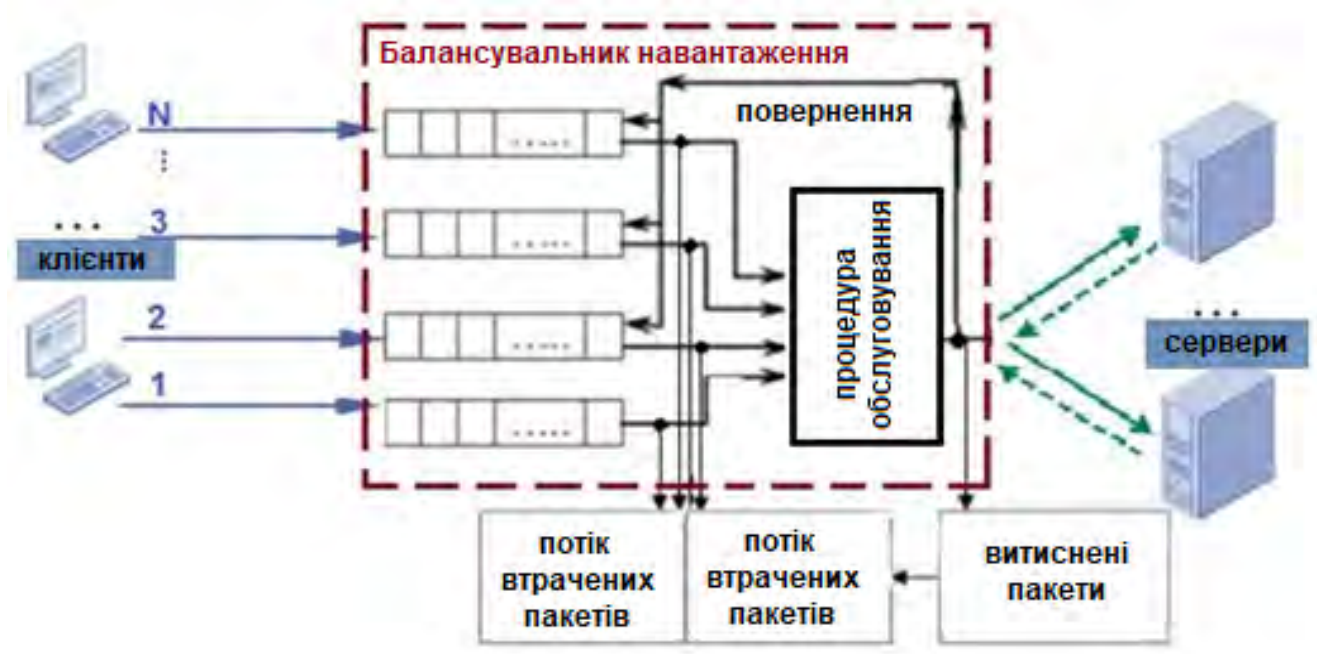

Рис. 2. Система балансування навантаження ІТКМ

На підставі аналізу мультифрактальних властивостей вхідного трафіку запропоновано динамічний алгоритм балансування трафіку, який має наступні етапи роботи:

1. У трафіку, що надходить на вхід комутатора, виділяємо вікно фіксованої довжини, в якому визначаються основні фрактальні та статистичні характеристики вхідних потоків.

2. Проводимо збір і аналіз статистичної інформації доступної пропускної здатності $\operatorname{NETi(t),~стану~}$ серверів: CPUi(t) - обсяг вільного ЦПП і RAMi(t) обсяг вільної оперативної пам'яті і-го сервера в момент часу $\mathrm{t}$ відповідно.

3. На основі мультифрактальних властивостей та інтенсивностей потоків обчислюємо необхідну кількість ресурсів для кожного q-го класу обслуговування трафіку.

4. Проводимо розрахунок розподілу потоків по вузлах мережі з урахуванням класифікації трафіку і завантаженості серверів і каналів зв'язку. На основі отриманих даних розраховується завантаженість серверів на наступному кроці.

5. Розподіляємо трафік по серверам в межах кожного класу потоку.

6. Проводимо розподіл недооцінки розрахованого кількості ресурсів NETi(t), CPUi(t), RAMi(t).

7. Проводимо збір даних про завантаженість серверів і передачу їх в систему балансування навантаження для розрахунку нового розподілу потоків.

8. Пересуваємо вікно вперед на задану величину зсуву i здійснюємо аналіз трафіку і прогноз наступного значення завантаженості серверів.

Розроблюваний метод балансування навантаження повинен забезпечувати статистично рівномірний розподіл навантаження на серверах, високі показники продуктивності, пропускної спромож- ності, відмовостійкості (автоматично виявляючи збої вузлів і перерозподіляючи потік даних серед решти) і низький час відгуку, кількість службової інформації, кількість втрачених даних. Алгоритм балансування повинен розподіляти запити по серверам так, щоб відхилення завантаженості серверів від середнього значення було мінімальним.

\section{Висновки}

Таким чином, досвід проведення АТО та ООС на Сході країни показав необхідність розвитку i удосконалювання систем управління та зв'язку до рівня країн членів НАТО. Розвиток і застосування інформаційних і телекомунікаційних технологій в довгостроковій перспективі докорінно змінять структуру і принципи побудови системи зв'язку, організаційних структур військових частин i підрозділів зв'язку. Це обгрунтовує доцільність використання єдиного підходу щодо оцінки пропускної спроможності в ІТКМ ПС та формування рекомендацій щодо балансування навантаження мережі під час передачі інформації.

Визначено, що пропускна спроможність системи зв'язку повинна бути такою, щоб в самих складних умовах обстановки конкретне значення показника якості пропускної спроможності було не нижчі вимагаємого.

Пропускна спроможність досягається: організацією необхідної кількості ліній зв'язку між вузлами та їх ефективним використанням; високою оперативністю розподілу каналів зв'язку та групових трактов; застосування на пунктах управління засобів автоматизації передачі інформації; введенням пріоритету на представлення зв'язку; чіткої організації оперативно-технічної служби та постійним контролем за проходженням інформації на вузли зв'язку. Мета досліджень досягнута. 


\section{Список літератури}

1. Мажара І.П. Інформаційна модель допуску осіб групи керівництва польотами до управління повітряним рухом/ I.П. Мажара, О.І. Тимочко, В.Г. Чернов // Наука і техніка Повітряних Сил Збройних Сил України. - 2018. - № 1(30). C. 24-29. https://doi.org/10.30748/nitps.2018.30.04

2. Скрынникова Н.С. Зарубежный опыт борьбы с терроризмом: механизмы противодействия / Н.С. Скрынникова // Науковий вісник Ужгородського національного університету. - 2014. - № 28(3). - С. 37-40.

3. Бовда Е.М. Концептуальні основи синтезу автоматизованої системи управління зв'язком військового призначення / Е.М. Бовда, Ю.А. Плуговий, В.А. Романюк // Збірник наукових праць ВІТІ. - 2016. - № 1. - С. 6-18.

4. Буренин А.Н. Теоретические основы управления современными телекоммуникационными сетями / А.Н. Буренин, В.И. Курносов. - М.: Наука, 2011. - 463 с.

5. Высочина О.С. Анализ систем мониторинга телекоммуникационных сетей / О.С. Высочина, С.И. Шматков, Салман Амер Мухсин // Радіоелектроніка, інформатика, управління. - 2010. - № 2. - С. 139-142.

6. Романюк B.A. Мережі MANET. Основа створення перспективної системи зв'язку тактичної ланки управління / В.А. Романюк, О.Я. Сова. - К.: МО, 2016. - 52 с.

7. Sahandi R. Wireless technology in the evolution of patient monitoring on general hospital wards / R. Sahandi // Journal of Medical Engineering \& Technology. - 2010. - № 34. - P. 51-63.

8. Beyer B. Site Reliability Engineering: How Google Runs Production Systems / B. Beyer. - Boston: O'Reilly Media, 2016. $-552 \mathrm{p}$.

9. Stefanov K. Dynamically Reconfigurable Distributed Modular Monitoring System for Supercomputers (DiMMon) / K. Stefanov // Procedia Computer Science. - 2015. - № 66. - P. 625-634.

10. Bronk C. The cyber attack on Saudi Aramco / C. Bronk // Survival. - 2013. - № 55(2). - P. 81-96.

11. Knopová M. The Third World War? In The Cyberspace. Cyber Warfare in the Middle East / K. Knopová // Acta Informatica Pragensia. - 2013. - № 3(1). - P. 23-32.

12. Пермяков О.Ю. Інформаційно - телекомунікаційні технології і сучасна збройна боротьба / О.Ю. Пермяков, Н.О. Королюк // Збірник матеріалів науково-технічної конференції молодих учених “Актуальні проблеми інформаційних технологій”. - Київ, 20-21 листопада 2018 р. - С. 5-6.

13. Korolyuk N. An approach to prediction of the telecommunication network quality parameters under the conditions of non-stochastic uncertainty / N. Korolyuk // Telecommunications and Radio Engineering. - 2017. - № 11. - P. 1027-1032.

14. Korolyuk N. Hybrid model of knowledge for situation recognition in airspace / N. Korolyuk // Automatic Control and Computer Sciences. - 2014. - № 49. - P. 16-25.

15. Selecting a model of unmanned aerial vehicle to accept it for military purposes with regard to expert data / A. Alimpiev, P. Berdnik, N. Korolyuk, O. Korshets, M. Pavlenko // Eastern-European Journal of Enterprise Technologies. - 2017. - № 1(85). - P. 53-60.

16. Результати аналізу основних класів безпілотних літальних апаратів для оцінювання можливості їх спільного застосування $з$ армійською авіацією/ А.М. Алімпієв, М.І. Ватан, В.В. Тюрін, В.І. Масягін // Системи озброєння i військова техніка. - 2016. - № 1(45). - С. 6-9.

17. Saatya T. Structures in decision making: On the subjective geometry of hierarchies and networks / T. Saatya // European Journal of Operational Research. - 2009. - № 3(199). - 867-872.

18. Пермяков О.Ю. Роль і місце інформаційних технологій в системі державно-оперативного військового управління з точки зору сучасних уявлень / О.Ю. Пермяков, Н.О. Королюк // Збірник матеріалів ІІІ міжнародної науковопрактичної конференції “Застосування космічних та геоінформаційних систем в інтересах національної безпеки та оборони”. - Київ, 5 квітня 2018 р. - С. 81-84.

19. Пермяков О.Ю. Інформаційно-телекомунікаційні технології і сучасна збойна боротьба / О.Ю. Пермяков, Н.О. Королюк // Збірник матеріалів науково-технічної конференції молодих учених “Актуальні проблеми інформаційних технологій”. - Київ, 20-21 листопада 2018 р. - С. 88.

20. Королюк Н.О. Процедура формалізації даних, які використовуються при описі процесу управління рухом повітряних об'єктів / Н.О. Королюк, Р.В. Корольов, О.А. Коршець // Связь, радиотехника, акустика и навигация. - 2017. № 4(53). - C. 103-106.

\section{References}

1. Mazhara, I.P., Timochko, O.I. and Chernov, V.G. (2018), "Informacijna model dopusku osib grupi kerivnictva pol'otami do upravlinnya povitryanim ruhom" [Information model of the admission of persons of group of the management of flights to air traffic control], Science and Technology of the Air Forces of Ukraine, No. 1(30), pp. 24-29. https://doi.org/10.30748/nitps.2018.30.04.

2. Skrynnikova, N.S. (2014), “Zarubezhnyj opyt bor'by s terrorizmom: mekhanizmy protivodejstviya” [Foreign Experience in Combating Terrorism: Mechanisms of Resistance], Scientific Bulletin of Uzhgorod National University, No. 28(3), pp. 37-40.

3. Bovda, Y.M., Plugovoy, Y.A. and Romanyuk, V.A. (2016), "Kontseptual'nyye osnovy sinteza avtomatizirovannoy sistemy upravleniya svyaz'yu voyennogo naznacheniya" [Conceptual bases for synthesis of an automated military communications control system], Collection of Scientific Works of VITI, No. 1, pp. 6-18.

4. Burenin, A.N. and Kurnosov, V.I. (2011), "Teoreticheskiye osnovy upravleniya sovremennymi telekommunikatsionnymi setyam" [Theoretical foundations of the management of modern telecommunication networks], Nauka, Moscow, $463 \mathrm{p}$. 
5. Vysochyna, O.S., Shmatkov, S.Y. and Salman, A.M. (2010), “Analyz system monytorynha telekommunykatsyonnykh setey" [Analysis of monitoring systems for telecommunication networks], Radio Electronics, Computer Science, Management, No. 2, pp.139-142.

6. Romanyuk, V.A. and Sova, O.Y. (2016), "Merezhi MANET. Osnova stvorennya perspektyvnoyi systemy zvyazku taktychnoyi lanky upravlinnya" [MANET Networks. The basis for the creation of a promising tactical link communication system], Ministry of Defence, Kyiv, $52 \mathrm{p}$.

7. Sahandi, R. (2010), Wireless technology in the evolution of patient monitoring on general hospital wards, Journal of Medical Engineering \& Technology, No. 34, pp. 51-63.

8. Beyer, B. (2016), Site Reliability Engineering: How Google Runs Production Systems, O'Reilly Media, Boston, 552 p.

9. Stefanov, K. (2015), Dynamically Reconfigurable Distributed Modular Monitoring System for Supercomputers (DiMMon), Procedia Computer Science, No. 66, pp. 625-634.

10. Bronk, C. (2013), The cyber attack on Saudi Aramco, Survival, No. 55(2), pp. 81-96.

11. Knopová, M. (2013), The Third World War? In The Cyberspace. Cyber Warfare in the Middle East, Acta Informatica Pragensia, No. 3(1), pp. 23-32.

12. Permyakov, O. and Korolyuk, N. (2018), "Informatsiyno-telekomunikatsiyni tekhnolohiyi i suchasna zbroyna borot'ba" [Information and telecommunication technologies and modern armed struggle], Collection of materials Scientific and technical conference of young students "Actual Problems of Information Technologies", 20-21 November, Kyiv, Ukraine, pp. 5-6.

13. Korolyuk, N. (2017), An approach to prediction of the telecommunication network quality parameters under the conditions of non-stochastic uncertainty, Telecommunications and Radio Engineering, No. 11, pp. 1027-1032.

14. Korolyuk, N. (2014), Hybrid model of knowledge for situation recognition in airspace, Automatic Control and Computer Sciences, No. 49, pp.16-25.

15. Alimpiev, A., Berdnik, P., Korolyuk, N., Korshets, O. and Pavlenko, M. (2017), Selecting a model of unmanned aerial vehicle to accept it for military purposes with regard to expert data, Eastern-European Journal of Enterprise Technologies, No. 1(85), pp. 53-60.

16. Alimpiiev, A.M., Vatan, M.I., Tiurin, V.V. and Masiahin, V.I. (2016), "Rezultaty analizu osnovnykh klasiv bezpilotnykh litalnykh aparativ dlia otsiniuvannia mozhlyvosti yikh spilnoho zastosuvannia z armiiskoiu aviatsiieiu" [The result of analysis of great classes unmanned aircraft for evaluation the opportunity of joint employment with army aviation], Systems of Arms and Military Equipment, No. 1(45), pp. 6-9.

17. Saatya, T. (2009), Structures in decision making: On the subjective geometry of hierarchies and networks, European Journal of Operational Research, No. 3(199), pp. 867-872.

18. Permyakov, O.Yu. and Korolyuk, N.O. (2018), "Rol i misce informacijnyx texnologij v systemi derzhavnooperatyvnogo vijskovogo upravlinnya z tochky zoru suchasnyx uyavlen" [Zastosuvannia kosmichnykh ta heoinformatsiinykh system v interesakh natsionalnoi bezpeky ta oborony], III th International Scientific Conference on the Application of Space and Geoinformation Systems for National Security and Defense "Application of space and geoinformation systems in the interests of national security and defense" 5 April, Kyiv, Ukraine, pp. 81-84.

19. Permyakov, O.Yu. and Korolyuk, N.O. (2018), "Informacijno-telekomunikacijni texnologiyi i suchasna zbrojna borotba" [Information and telecommunication technologies and modern malfunction], Collection of Materials of Scientific and Technical Conference of Young Scientists "Actual Problems of Information Technologies”, 20-21 November, Kyiv, Ukraine, pp. 88.

20. Korolyuk, N.O., Korolov, R.V. and Korshecz, O.A. (2017), "Procedura formalizaciyi danyx, yaki vykorystovuyutsya pry opysi procesu upravlinnya ruxom povitryanyx obyektiv" [The procedure for formalizing data used to describe the process of controlling the movement of air objects], Communication, Radio Engineering, Acoustics and Navigation, No. 4(53), pp. $103-106$.

\section{Відомості про авторів:}

Королюк Наталія Олександрівна
кандидат технічних наук
доцент кафедри
Харківського національного університету
Повітряних Сил ім. І. Кожедуба,
Харків, Україна
https://orcid.org/0000-0002-2865-5899

Голубничий Дмитро Юрійович кандидат технічних наук доцент доцент кафедри

Харківського національного університету

Повітряних Сил ім. І. Кожедуба,

Харків, Україна

https://orcid.org/0000-0003-1719-7586

\section{Information about the authors:}

\author{
Natalia Korolyuk \\ Candidate of Technical Sciences \\ Senior Lecturer of the Department \\ of Ivan Kozhedub Kharkiv \\ National Air Force University, \\ Kharkiv, Ukraine \\ https://orcid.org/0000-0002-2865-5899
}

\author{
Dmitry Golubnychy \\ Candidate of Technical Sciences \\ Associate Professor Senior Lecturer \\ of the Department of Ivan Kozhedub Kharkiv \\ National Air Force University, \\ Kharkiv, Ukraine \\ https://orcid.org/0000-0003-1719-7586
}


Поліщук Ярослав Григорович

старший офіцер відділу в/ч А0306, Вінниця, Україна

https://orcid.org/0000-0001-7359-8750
Yaroslav Polishchuk

Senior Officer A0306,

Vinnitsa, Ukraine

https://orcid.org/0000-0001-7359-8750

\title{
ОБОСНОВАНИЕ ПОДХОДА ПО ОЦЕНКЕ ПРОПУСКНОЙ СПОСОБНОСТИ ИНФОРМАЦИОННО-ТЕЛЕКОММУНИКАЦИОННЫХ СЕТЕЙ ВОЗДУШНЫХ СИЛ
}

\author{
Н.А. Королюк, Д.Ю. Голубничий, Я.Г. Полищук
}

В статье в результате проведенного анализа установлено, что основой информационной инфраструктурой являются современные мультисервисные телекоммуникационные сети, эффективность функиионирования которых с учетом опыта операции объединенных сил зависит от степени автоматизации и интеллектуализации. Определена важность оиенки пропускной способности информационно-телекоммуникационной сети Воздушных Сил, которая показывает максимальный объем информаџии, переданный в единииу времени, а именно скорость выполнения внутренних сетевых операций. В результате проведенного анализа последних исследований и публикаций установлено, что знание общей пропускной способности между двумя узлами не дает полной информации о возможных путях ее повыщения. Данные о пропускной способности отдельных элементов сети могут быть полезны для принятия решения о способах ее оптимизации. Установлено, что необходимо определить общую пропускную способность сети как среднее количество информации, передаваемой между всеми узлами сети в единииу времени. Обоснована целесообразность использования единого подхода по оиенке пропускной способности в информационно-телекоммуникационных сетях Воздушных Сил и формирования рекомендаций по балансировке нагрузки сети при передаче информации. Предложен метод балансировки, который обеспечивает статистически равномерное распределение нагрузки на серверах, высокие показатели производительности, пропускной способности, отказоустойчивости и низкое время отклика, количество служебной информации, количество потерянных данных. Определено, что пропускная способность системы связи должсна быть такой, чтобы в самых сложных условиях обстановки конкретное значение показателя качества пропускной способности было не ниже требуемого. Установлено, что пропускная способность достигается: организацией необходимого количества линий связи между узлами и их эффективным использованием; высокой оперативностью распределения каналов связи и групповых трактов; применением на пунктах управления средств автоматизации передачи информаиии; введением приоритета на предоставление связи; четкой организацией оперативно-технической службы и постоянным контролем за прохождением информачии на узлах связи.

Ключевые слова: оценка пропускной способности сети, информационно-телекоммуникачионная сеть Воздушных Сил, метод балансировки нагрузки.

\section{FEATURES OF AUTOMATION OF DECISION-MAKING PROCESSES IN THE ASSESSMENT OF THE AIR SITUATION AT AIR FORCE CONTROL POINTS OF THE ARMED FORCES OF UKRAINE}

N. Korolyuk, D. Golubnychy, Y. Polishchuk

As a result of the analysis, the article established that the basis of the information infrastructure is modern multiservice telecommunication networks, the effectiveness of which, taking into account the experience of the combined forces operation, depends on the degree of automation and intellectualization. The importance of assessing the capacity of the information and telecommunication network of the Air Force, which shows the maximum amount of information transmitted per unit of time, namely the speed of internal network operations, is determined. As a result of the analysis of recent studies and publications, it was found that knowledge of the overall throughput between two nodes does not provide complete information about the possible ways to increase it. Data on the throughput of individual network elements can be useful for deciding on how to optimize it. It was found that it is necessary to determine the total network bandwidth as the average amount of information transmitted between all nodes of the network per unit time. The feasibility of using a single approach to assess the capacity in the information and telecommunication networks of the Air Force and the formation of recommendations on balancing the network load when transmitting information is substantiated. A balancing method is proposed that provides a statistically uniform load distribution on the servers, high performance, throughput, fault tolerance and low response time, the amount of overhead information, and the amount of lost data. It is determined that the throughput of the communication system should be such that, in the most difficult conditions, the specific value of the throughput quality indicator is not lower than required. It has been established that throughput is achieved: by organizing the required number of communication lines between nodes and their efficient use; high efficiency of distribution of communication channels and group paths; the use of information transfer automation equipment at control points; the introduction of priority on the provision of communication; a clear organization of operational and technical services and constant monitoring of the flow of information at communication centers.

Keywords: Network bandwidth estimation, Air Force information and telecommunication network, load balancing method. 